\title{
PEMIMPIN NARSISISTIK DALAM ORGANISASI GEREJA
}

\author{
Ivan Th. J. Weismann dan Johana B. Tumbol
}

\begin{abstract}
ABSTRAK
Beberapa pemimpin memiliki gangguan kepribadian narsistik atau menampilkan unsur narsistik dalam kepemimpinannya. Yang dicari dan dibutuhkan pemimpin narsistik dalam kepemimpinannya adalah dukungan dan penghormatan jemaat untuk menutupi perasaan kepribadian mereka yang tidak memadai. Untuk itu mereka mengembangkan kemampuan mereka untuk memanipulasi orang lain dan selalu berusaha tampil atraktif dalam mengembangkan kecakapan interpersonal. Hasilnya ialah mereka mendapatkan pengikut yang memenuhi kebutuhan mereka itu. Untuk itu sangat penting melalui tulisan ini membahas tentang karakteristik kepemimpinan narsisistik dalam gereja dan bagaimana menanangani kepemimpinan narsisitik tersebut.
\end{abstract}

Kata kunci: pemimpin narsisistik; kepribadian; gereja; jemaat; gembala;

\section{PENDAHULUAN}

Ada hubungan langsung antara tingginya tingkat narsistik dalam kepemimpian penggembalaan dengan konflik dalam organisasi gereja. Puls dan Ball merekomendasikan bahwa ada hubungan antara pendeta narsisistik dan konflik destruktif yang terjadi di dalam gereja yang mereka layani. (Darrell Puls dan R. Glenn Ball, 2015: $10)$.

Ada lima karakteristik kepribadian utama yang menyebabkan konflik dalam jemaat: konsep diri negatif, agresi, kekakuan yang berlebihan, otoritarianisme, dan narsisisme. $90 \%$ dari pendeta di Belanda yang memiliki peringkat tinggi dalam karakteristik narsisistik diantaranya adalah sebagai berikut: tidak disamarkan (69\%), tersamarkan (18\%), seimbang $(9 \%)$, dan rentan $(3 \%)$. Pendeta yang karakterisitik narsisistiknya tersamarkan sebagian besar dapat menjalankan pelayanannya dengan cara yang cukup sehat dengan memfokuskan narsisistik mereka ke dalam saluran positif. Ini adalah $18 \%$ yang dikategorikan sebagai tersamarkan. 3\% yang disebut sebagai rentan adalah yang mencoba untuk menyembunyikan tingkat narsistik mereka yang berbahaya dari diri mereka sendiri dan dari orang lain (Darrell Puls dan R. Glenn Ball, 2015: 1).
Persentase gangguan kepribadian narsisitik, baik secara terang-terangan maupun terselubung pada diri pemimpin, ialah lebih 20 persen terdapat pada semua gereja yang mengalami konflik internal, ini menunjukkan adanya korelasi yang kuat antara narsistik dengan konflik. (Darrell Puls dan R. Glenn Ball, 2015: 10). Ini disebabkan oleh karena karakteristik kepribadian narsistik tersebut. Pemimpin dengan ke-pribadian narsisitik memiliki kebutuhan untuk mendapatkan pengakuan sebagai pakar yang berwenang, kurangnya empati, kebutuhan untuk selalu menjadi benar, ketidakmampuan untuk memaafkan, dorong-an untuk membalas dendam dan kesediaan untuk memanipulasi, memperalat, dan mengucilkan angota jemaat, yang kesemuanya ini adalah kebalikan dari kepribadian Kristus (Darrell Puls dan R. Glenn Ball, 2015: 10). Tulisan ini akan membahas lebih dalam lagi karakteristik kepribadian narsisistik terebut dalam diri pemimpin dalam pelayanannya di organisasi gereja. Selain itu juga akan membahas tentang bagaimana menghadapi pemimpin narsistik tersebut.

\section{Asal mula dan pengertian istilah Narsis}

Istilah narsis berasal dari dongeng Yunani yang menceritakan tentang seorang 
bernama Narcissus yang digambarkan sebagai seorang anak laki-laki berusia enam belas tahun yang begitu tampan, sehingga dengan ketampanannya itu membuat banyak orang tertarik padanya, tetapi juga oleh ketampanannya itu membuat dia sendiri tidak dapat menjalin hubungan dengan orang lain dan mencintai orang lain, oleh karena dia jatuh cinta dengan gambar dan citranya sendiri. Dia begitu terpaku oleh bayangannya sendiri yang terbaring dan tersimpan di dalam kolam. Narcissus mewakili orang yang berfokus pada dirinya sendiri yang memiliki rasa lapar yang mendalam akan pujian yang berlebihan, juga perasaan superioritas yang kuat dan reaksi yang kuat terhadap penolakan orang lain terhadap dirinya. Seorang Narsistik itu tidak mampu memiliki empati dan koreksi atau instropeksi diri dan memanfaatkan orang lain untuk kepentingan pribadinya.

Seorang narsisistik sering didefinisikan sebagai orang yang sibuk dengan impian kesuksesan, kekuatan, kecantikan, dan kecemerlangan. Seorang narsisistik juga suka mencari dan menginginkan perhatian dan kekaguman dari orang lain. Ancaman terhadap harga diri seorang narsis akan diikuti dengan perasaan marah, pembangkangan, malu, dan penghinaan. Narsis juga akan menampilkan rasa berhak, dengan harapan untuk mendapatkan perlakuan khusus, tanpa perlu mengambil tanggung jawab timbal balik sebagai imbalan.

Mereka juga tidak mau membalas kebaikan orang lain, dan tidak dapat dieksploitasi secara interpersonal. Narsistik juga memiliki rasa mengutamakan kepentingan diri atau keistimewaannya, di mana mereka membesar-besarkan bakat dan prestasi khusus mereka. Akhirnya, narsistik cenderung marah, malu, rendah diri, dan merasa terhina ketika mereka dikritik oleh orang lain (Granville King III, 2007:4). Lebih jelasnya untuk pengenalan karakteris-tik kepribadian narsistik ini adalah sebagai berikut.

\section{Tanda memiliki kepribadian narsistik}

Gangguan kepribadian tersebut meresap dan muncul di banyak area kehidupan. Gangguan kepribadian ini terlihat jelas pada masa remaja atau dewasa awal dan tidak dapat disebabkan oleh efek fisiologis dari kecanduan narkoba. Paling kurang menurut Downing (2013) lima saja dari beberapa karakteristik berikut jika dipenuhi oleh seseorang maka ia dapat didiagnosis Gangguan Kepribadian Narsis-tik:

- Rasa mementingkan diri yang besar di mana dia melebih-lebihkan pencapaian dan kemampuan dirinya dan mengharapkan untuk dirinya diakui lebih unggul dari yang lain.

- Memiliki Fantasi kesuksesan, kekuasaan, kecemerlangan, keindahan, atau cinta ideal yang tidak terbatas.

- Keyakinan bahwa dirinya itu istimewa atau unik dan hanya boleh bergaul dengan orang-orang khusus.

- Membutuhkan kekaguman yang berlebihan dari orang lain.

- Rasa berhak yang melibatkan harapan untuk mendapatkan peng-ikut yang mendatangkan keuntungan atau kepatuhan otomatis terhadap dirinya.

- Eksploitasi terhadap orang lain untuk mencapai tujuan pribadinya dan untuk mendapatkan apa pun yang diinginkan atau dibutuhkannya.

- Tidak memiliki empati dan keinginan untuk mau mengenali kebutuhan atau perasaan orang lain dan memandang kebutuhan dan perasaan orang lain sebagai sebagai kelemahan.

- Iri pada orang lain dan percaya bahwa orang lain juga iri pada dirinya. 
- Berperilaku dan bersikap sombong dan angkuh.

Salah satu penyebab gangguan kepribadian narsistik adalah keadaan yang secara psikologis kosong dan cemas dengan perasaan diri yang goyah dan harga diri yang rendah yang merupakan kebalikan dari citra diri yang diproyeksikannya. Selain itu, seorang narsistik sering memiliki luka yang mendalam pada masa kecil (Downing: 2013).

Gangguan kepribadian narsistik secara psikodinamik berhubungan dengan pola pengasuhan pada masa kanak-kanak. Oakley menjelaskan bahwa timbulnya kepribadian narsis diawali oleh disfungsional pada masa kanak-kanak. Kepribadian narsistik menurut Bornstein adalah akibat dari individu yang selalu berusaha untuk membuktikan keberhargaan dirinya dan berupaya mendapat penghormatan dari orang lain untuk mengatasi perasaan penolakan dan ketidakberhargaan dirinya yang dialami sejak masa kanak-kanak (Weismann, 2017: 16-17).

\section{Kurangnya empati seorang narsisistik.}

Pelayanan dalam jemaat membutuhkan ekspresi empati yang mendalam, yang tidak mampu dihasilkan oleh seorang narsisistik. Oleh karena itu, tam-pilan empati gembala yang narsis sebenarnya adalah tindakan yang dirancang untuk memanipulasi jemaat agar jemaat memberikan apa yang paling dibutuhkan gembala tersebut, berupa: ungkapan rasa terima kasih, kekaguman, keuntungan pribadi yang dibutuhkan secara narsistik oleh gembala tersebut (Darrell Puls dan R. Glenn Ball, 2015: 10). Kemampuan berempati hanya berlangsung sementara untuk beberapa waktu selama jemaat memenuhi kebutuhan gembala tersebut. Empati gembala akan berakhir dan berubah menjadi menyerang dan mengucilkan jemaat yang tidak lagi menyediakan kepentingan gembala yang memadai.

\section{Mengkambinghitamkan orang lain}

Kebutuhan narsisis lainnya ialah seseorang yang dapat dijadikannya kambing hitam untuk melampiaskan kemarahannya. Gembala narsistik tidak dapat menganggap dirinya bersalah atau membuat kesalahan, dia harus selalu memiliki orang lain untuk disalahkan atas apa yang salah. Seringkali kambing hitam itu adalah bawahannya yang akan dikucilkan dan diserang tanpa henti sampai bawahannya itu pergi, pada saat itu ia perlu mencari lagi kambing hitam lainnya.

Jika tidak ada bawahannya, gembala narsis cenderung mencari kambing hitam itu pada jemaat untuk menjadi sasaran serangannya. Serangan-serangan itu membuat jemaat yang menjadi target sasaran menjadi bingung, putus asa, dan kadangkadang mengakibatkan iman jemaat dirusakkan. Di suatu gereja besar, setiap anggota staf telah menulis surat pengunduran diri. Di gereja yang lain, seorang gembala senior dengan gangguan kepribadian narsistik yang tersembunyi telah memecat 21 gembala; hanya satu gembala yang masih tinggal dalam pelayanan tersebut (Darrell Puls dan R. Glenn Ball, 2015: 11).

\section{Persoalan dalam relasi bagi narsisis}

Relasi dengan narsisis tidak mudah. Berikut ini Downing (2013) mengemukakan beberapa masalah yang mungkin dimiliki oleh Anda ketika berelasi dengan seorang narsis:

- Mereka sangat menarik dan karismatik untuk menarik Anda ke dalam relasi dengan mereka.

- Anda menjadi kehilangan rasa terhadap "diri" dan kebutuhan, dan keinginan Anda sendiri.

- Dalam hubungan itu akan lebih mengutamakan kebutuhan, perasaan dan kekhawatiran narsisis, sementara perasaan, kebutuhan, dan ke- 
khawatiran Anda menjadi tidak penting.

- Anda harus menghabiskan energi untuk memastikan narsisis merasa penting, dikagumi, dan spesial.

- Anda merasa dikendalikan dan mengalami kesulitan mengatakan tidak.

- Hubungan itu menghabiskan banyak energi Anda.

- Mereka sulit untuk ditangani.

- Mereka peka terhadap kritik dan bereaksi dengan kemarahan atau rasa malu.

- Mereka perfeksionis dan tidak toleran terhadap kesalahan orang lain dan bereaksi berlebihan terhadap kesalahan orang lain itu.

- Mereka memiliki tuntutan dan harapan yang tidak realistis terhadap orang lain.

- Anda akan mengalami penderitaan emosional.

- Mereka tidak dapat melihat masalah masalah atau kelemahan pribadi dalam diri mereka sendiri.

- Mereka perlu merasakan "sebagai yang ditinggikan" oleh Anda setiap saat.

- Mereka tidak bersikap empatik terhadap Anda atau terhadap anak-anak.

- Mereka tidak peduli dengan bagaimana mereka memengaruhi Anda dan memperlakukan Anda.

- Mereka tidak dapat memberikan cinta tanpa syarat atau persetujuan atau pengakuan terhadap indi-vidualitas orang lain.

\section{Pola kepemimpinan karismatik dalam diri seorang narsisistik}

Ciri-ciri kepemimpinan karismatik dalam diri seorang narsisitik dikemukakan oleh Granville King III sebagai berikut. Kepemimpinan karismatik adalah emosional, di mana "pengikut diilhami dengan antusias agar memberikan ketaatan, loyalitas, komitmen, dan pengabdian yang tidak boleh dipertanyakan kepada pemimpin". Adapun perbedaan pemimpin karismatik dari pemimpin lain ialah oleh kemampuan mereka untuk merumuskan dan meng-artikulasikan visi inspirasional melalui perilaku dan tindakan yang menumbuhkan kesan bahwa mereka dan pelayanannya adalah luar biasa. Pemimpin yang karismatik sebagai seseorang visioner (yaitu, secara konsisten mengartikulasikan visi yang memikat, menetapkan harapan yang tinggi, dan menjadikan perilakunya sebagai model), energizer (yaitu, mendemonstrasikan kegembiraan pribadi, mengekspresikan kepercayaan diri pribadi, dan mencari, menemukan, dan menggunakan kesuksesan), dan akhirnya, suporter (yaitu, mengekspresikan dukungan pribadi, berempati, dan mengekspresikan kepercayaan pada orang lain). (Granville King III, 2007 :3)

Gaya kepemimpinan karismatik pada seorang narsisitik juga dapat menghasilkan hasil yang buruk bagi jemaat, karyawan dan organisasi jika terjadi krisis. Misalnya, pemimpin karismatik yang rentan terhadap narsisisme ekstrem, dapat menuntun diri mereka untuk mempromosikan tujuan-tujuan yang sangat melayani diri mereka sendiri dan muluk-muluk. Perilaku pemim-pin karismatik yang narsisistik dapat menjadi berlebihan, kehilangan kontak dengan realitas, atau menjadikan orang lain sebagai kendaraan untuk keuntungan pribadi.

Lebih jauh lagi, narsisisme dapat memimpin para pemimpin yang karismatik untuk melebih-lebihkan kemampuan mereka dan meremehkan peran keterampilan yang penting pada diri orang lain. Akhirnya, pemimpin narsistik, yang memiliki rasa mementingkan diri yang kuat, ditambah dengan kebutuhan untuk menjadi pusat perhatian, akan sering mengabaikan sudut pandang orang lain dalam organisasi, serta pengem- 
bangan kemampuan kepemimpinan bagi pengikut mereka. Perilaku seperti itu mungkin tidak hanya merugikan pemimpin, tetapi juga jemaat, karyawan, serta organisasi yang potensial. (Granville King III, 2007 $: 4)$.

Seorang narsis di usia dewasa selalu melekat dalam mimpinya bahwa satu hari ia akan melakukan sesuatu yang benar-benar luar biasa dan belum pernah terjadi sebelumnya untuk dipersembahkan bagi pengagumnya dan bagi Tuhan. Mereka berfantasi tentang menulis buku terlaris yang akan mengubah jalannya sejarah gereja, atau menginjili bangsa, atau mendirikan satu gereja yang sejati, atau mengatasi masalah kelaparan dunia, atau menjadi seorang komandan tentara Tuhan di akhir zaman. Mereka memiliki rasa yang besar tentang betapa pentingnya dirinya. Mereka merasa berhak untuk mencapai sukses yang tidak terbatas.

Mereka percaya bahwa mereka layak mendapat pujian dari manusia seperti yang diberikan kepada Tuhan. Mereka secara potensial berbahaya karena mereka membutuhkan umat untuk memberikan tepuk tangan yang meriah terhadap visi dan kebajikan mereka dan untuk membenarkan segala tindakan mereka. Ketakutan terbesar mereka dalam hidup ini adalah menjadi orang yang tidak penting, tidak terkenal dan kehilangan muka (Weismann, 2017: 15).

Untuk mendapatkan dukungan publik yang ia butuhkan, para pemimpin narsistik ini sering membuat klaim yang luar biasa bagi dirinya sendiri atau menyuruh orang lain mencapai klaim itu untuk ke-pentingan pribadinya. Klaim tersebut dapat mencakup urapan khusus, pengorbanan pribadi yang tidak biasa, pertemuan dengan Tuhan yang belum pernah terjadi sebelum-nya, pelatihan yang unik, pengajaran atau karunia kepemimpinan yang unik, wahyu kebenaran yang tidak dimiliki oleh orang lain, atau pengetahuan rahasia tentang rencana Tuhan di akhir zaman. Semua klaim itu menyiratkan bahwa Allah memiliki panggilan khusus pada pemimpin narsistik ini, sehingga kewajiban bagi orang yang "bukan orang khusus" ialah harus mengaguminya dan menjadi pengikutnya. Pernah ada pemimpin yang mengklaim tentang keistimewaan dirinya dan betapa pentingnya dirinya sehingga membuat sangat sulit bagi pengikut untuk menentangnya. Hal ini memungkinkan dia untuk bertindak sesukanya dalam mengendalikan pengikutnya (Weismann, 2017: 15-16).

\section{Gembala yang Narsisistik}

Jika gangguan kepribadian narsisistik pada gembala adalah antitesis dari Kristus sebagai gembala yang baik, kita bertanyatanya apakah ada perbedaan antara populasi non-narsistik dan narsistik dalam hal pelayanan dan praktik kehidupan spiritual. Kemarahan dan kebutuhan ego pada narsisistik dikontraskan dengan harapan akan kerendahan hati, damai dan keteraturan spiritual dan agama. "Kasihilah sesamamu manusia seperti dirimu sendiri" (Mat. 19:19) dan "Sebagaimana kamu kehendaki supaya orang perbuat kepadamu, perbuatlah juga demikian kepada mereka" (Lukas 6:31) akan tampak asing dan bahkan sulit dimengerti oleh orang dengan ganggu-an narsisistiknya. Berikut ini adalah pen-jelasan tentang kepribadian narsisistik gembala dalam pelayanannya.

Puls dan Ball mendaftar enam tanda narsisme pada gembala: 1) dia menjadi semua pusat pengambilan keputusan; 2) ketidaksabaran atau kurangnya kemampuan untuk mendengarkan orang lain; 3) mendelegasikan tanpa memberikan otoritas atau dengan terlalu banyak batasan; 4) perasaan berhak; 5) merasa terancam atau terintimidasi oleh staf yang berbakat; dan 6) sangat perlu menjadi yang terbaik dan 
tercerdas di ruang lingkupnya. (Darrell Puls dan R. Glenn Ball, 2015: 3).

Peneliti Belanda Hessel Zondag menempatkan gembala ke dalam empat kelompok: 1) mereka yang memiliki orientasi alami yang menyebabkan mereka melihat agama sebagai cara hidup di mana mereka dapat menjalani kesalehan dan keyakinan mereka; 2) mereka yang berusaha menjaga keseimbangan antara iman dan keraguan meskipun mereka mungkin tidak sepenuhnya yakin dan sering menerima jawaban sementara terhadap masalahmasalah teologis utama; 3) mereka yang membutuhkan orang lain untuk membantu mereka membentuk dan memahami iman mereka; dan 4) gembala narsisistik yang "menggunakan agama untuk mendapat dukungan, keamanan dan jaminan sosial" (Darrell Puls dan R. Glenn Ball, 2015: 4).

Pemimpin dengan kepribadian narsistik juga berusaha memenuhi kebutuhannya berupa mempertahankan citra diri yang positif setiap saat, sebagai tanda ia berkenan kepada Tuhan dan melayani Tuhan dengan baik. Hal ini dicapai melalui merendahkan nilai orang lain agar dapat mempertahankan diri sebagai pejabat penting dalam gereja. Kebutuhan untuk mempromosikan signifikansi diri sendiri di dalam gereja terlihat dalam ketidakmampuan pejabat gereja dalam menerima kritik atas pribadinya dan kritik atas gerejanya namun berespon positif pada setiap individu yang menentangnya yang memilih untuk meninggalkan gereja (Weismann, 2017: 14).

Cara yang paling efektif untuk pemimpin narsisitk ini melakukan tindakan pengendalian atas pengikutnya adalah meyakinkan para pengikutnya bahwa mereka berada dalam sebuah misi yang luar biasa bersama dengan dia. Jika pemimpin narsisitik berhasil meyakinkan para peng-ikutnya bahwa ia adalah instrumen yang unik dari Tuhan, maka kepada pengikutnya dikatakan mereka menjadi unik juga ketika memberikan dukungan baginya. Kelompok ini mungkin akan mengatakan atau menyiratkan hal-hal seperti "Kami adalah gerakan khusus dari Tuhan," "Kami adalah satu-satunya kelompok yang mem-beritakan kebenaran," "Kami adalah umat tersisa yang setia," "Kami adalah ujung tombak Allah bagi generasi ini," atau " Kami berada dalam pusat pelatihan untuk dibentuk menjadi tentara Tuhan di akhir zaman" (Weismann, 2017: 16).

\section{Kelebihan narsisistik}

Ada dua kekuatan khusus untuk narsistis produktif yang menjadikan mereka pemimpin yang ideal: Mereka adalah visioner, dan mereka dapat menginspirasi banyak pengikut. Narsistis produktif adalah "tidak hanya pengambil risiko dalam menyelesaikan pekerjaan, tetapi juga pemikat yang dapat mengubah massa dengan retorika mereka. Sebagai visioner, pemimpin narsistik selalu melihat gambaran besar, dan cenderung meninggalkan analisis kepada orang lain. Ketika mereka tidak menyukai aturan, mereka mengabaikan, atau bahkan mengubahnya. Visi mereka adalah yang agung, karena mereka terinspirasi oleh kebutuhan akan kekuasaan, kejayaan, dan pengakuan. Dan melalui visi agung ini, ditambah dengan karisma besar, mereka mendapatkan kesetiaaan dari pengikut mereka. Pada gilirannya, para pengikut memenuhi kebutuhan pemimpin narsistik akan kekaguman, yang semakin memperkuat keyakinan dan percaya diri pemimpin terhadap visi mereka.

Namun, perlu berhati-hati dalam memuji kebaikan kepemimpinan narsistik. Oleh karena ada lima kelemahan yang narsistik yaitu, narsis adalah hipersensitif terhadap kritik, pendengar yang buruk, kurang empati, tidak mau atau tidak mampu untuk mentoring atau dimentor, dan selalu ingin berkompetitif. (Zeth A. Rosenthal, 
2017 :47). Kelebihan lainnya bagi narsisis konstruktif ialah percaya diri, bijaksana, dan realistis, bukannya tidak stabil, reaktif, dan menipu diri sendiri. Meskipun mereka menikmati ketika dikagumi, mereka memiliki apresiasi yang realistis atas kemampuan dan keterbatasan mereka. (Zeth A. Rosenthal, 2017 :48)

Adakah kondisi optimal untuk kepemimpinan narsistik? Narsisis berhasil atau gagal dalam kepemimpinan tidak hanya tergantung pada kepribadian mereka, tetapi juga pada keadaan di mana mereka memimpin. Narsisis mungkin lebih cenderung berhasil dalam posisi di mana karisma dan ekstraversi adalah penting (misalnya, pada penjualan), atau di mana penyerapan diri dan kepentingan diri adalah penting (misalnya, pada sains), tetapi tidak dalam posisi yang membutuhkan mem-bangun hubungan dan kepercayaan yang berkelanjutan. Mereka juga cenderung melakukan yang lebih baik dalam situasi di mana tujuan pribadi mereka dapat menyatu dengan tujuan dari pengikut dan organisasi mereka dari pada situasi di mana kesuksesan mereka datang dengan mengorbankan orangorang di sekitar mereka.

Narsisis adalah cenderung muncul, dan sering berkembang, pada waktu suatu tatanan baru didirikan, tetapi tidak mampu untuk menjaga stabilitas yang diperlukan untuk keberlanjutan tatanan baru ke masa depan (misalnya, Mao, yang mendirikan sebuah tatanan politik baru di sebuah negara yang besar dan kuat namun jutaan warganya kelaparan berpisah dengan sekutunya Soviet pada saat yang sama ia menghadapi konflik dengan AS mengenai Taiwan, dan hampir menghancurkan perekonomian China). Sementara pemimpin narsistik dapat berkembang dalam masa kacau, mereka mungkin juga tampak tidak pada tempatnya di saat-saat yang lebih tenang, dan akibatnya ia dihapus dari kekuasaan. Akhirnya, dan agak berlawanan, pemimpin narsisitik mungkin lebih sukses ketika mereka muda. Sementara banyak narsisis surut dalam ketundukan dan keputusasaan saat mereka menua di mana fakta kelemahan dan kegagalan mereka menjadi lebih jelas, namun pemimpin narsistik sering mampu menggunakan kekuatan sosial mereka untuk menangkis realitas yang mengganggu ini. Karena itu, mereka mungkin menjadi lebih muluk dan tirani seiring berjalannya waktu. (Zeth A. Rosenthal, 2017:49)

Sifat-sifat pemimpin narsistik juga dikemukakan oleh Harrelson bahwa pemimpin narsis didorong untuk menacapai sukses melalui kebutuhannya untuk dikagumi dan dipuji. Seringkali ia akan menunjukkan rasa diri lebih penting serta ambisi besar dan fantasi tentang kemegahan yang akan dicapainya. Para pemimpin ini umumnya sangat berpusat pada diri sendiri dan memiliki rasa ketidakpastian karena perasaan rendah diri yang mendalam.

Sering mereka tidak mampu menikmati setiap keberhasilan yang datang ke dalam kehidupan mereka. Dia memiliki ketidakpuasan dengan kehidupan secara lahiriah. Perasaan ketidakpuasannya nampak ketika ia akan berusaha untuk memiliki kontrol lebih banyak dalam kehidupan rohani jemaat yang sehari-harinya. Selain itu pemimpin ini akan terlibat dalam kehidupan jemaat dalam pengambilan keputusan tentang keuangan, pilihan karir, dan berbagai kehidupan jemaat sehari-hari. Hal yang menarik adalah bahwa beberapa jemaat membiarkan hal ini terjadi dalam hidup mereka dan tampaknya tidak menjadi persoalan dalam diri mereka (Weeismann, 2017:14).

Pemimpin narsistik ini terobsesi oleh keinginan untuk menjadi orang hebat atau melakukan sesuatu yang belum pernah terjadi sebelumnya bagi Allah. Untuk dapat mencapai fantasi ini membutuhkan kerjasama dari orang lain dan mendapatkan bantuan keuangan mereka. Pemimpin 
narsistik ini tidak ada keinginan secara sadar untuk menyakiti siapa pun; tetapi kenyataannya orang lain terluka ketika mereka dimanfaatkan untuk kepentingan pemimpin narsistik yang dibungkus sebagai 'rencana atau tujuan' Allah (Weismann, 2017: 14-15).

Pemimpin narsistik adalah bahwa mereka dipilih karena mereka melengkapi narsisisme pengikut mereka sendiri. Pemimpin narsistik adalah "cermin lapar" (yaitu, senantiasa mencari konfirmasi dan kekaguman untuk melawan rasa tak berdaya batinnya), sedangkan pengikut mereka adalah narsis yang "lapar" - mereka tidak lengkap sebagai individu dan hanya bisa menjadi berharga ketika mereka dapat berhubungan dengan individu yang dapat mereka kagumi melalui prestise, kekuasaan, kecantikan, kecerdasan, atau penampilan moral pemimpin mereka itu (Zeth A. Rosenthal, 2017 :50)

\section{Mengahadapi pemimpin narsisistik}

Anda tidak dapat membuat orang narsisis berubah. Gangguan kepribadian adalah masalah yang paling sulit secara psikologis untuk mengobatinya karena orang tersebut tidak memiliki wawasan tentang siapa mereka dan tidak memiliki kesadaran untuk perlu berubah. Upaya Anda untuk memaksa perubahan kemungkinan besar akan menyebabkan lebih banyak reaksi balik terhadap Anda. Anda perlu memfokuskan upaya Anda untuk mengubah diri sendiri. Hadapi kebenaran tentang siapa mereka, sesuaikan harapan Anda, memfokuskan kembali upaya Anda, dan belajar untuk mengurus diri anda sendiri. Berikut ini beberapa hal-hal yang dikemukakan Downing (2013) dapat Anda lakukan:

- Bekerjalah mengembangkan rasa terhadap "diri” yang kuat.

- Belajar untuk memvalidasi "diri Anda."
- Berhenti untuk berusaha membuat narsis

memvalidasi perasaan, pikiran, dan kebutuhan Anda.

- Hadir untuk kebutuhan Anda sendiri.

- Identifikasi hal-hal dalam diri Anda yang membuat Anda rentan terhadap perilaku narsisis.

- Identifikasi perilaku narsis sehingga Anda dapat membela diri terhadap mereka dan tidak terkejut ketika hal itu terjadi.

- Berhentilah mencoba menjelaskan diri Anda sendiri dan sebagai gantinya membuat pernyataan singkat tentang apa yang akan Anda lakukan dan tidak mau lakukan.

- Tentukan batasan yang jelas dan menolak untuk mundur.

- Mengembangkan keterampilan ketegasan.

- Putuskan hubungan jika perlu atau batasi interaksi jika terlalu meracuni. Jika narsisis menolak untuk menghormati batasan Anda atau melakukan pelecehan ketika Anda mulai peduli dengan diri anda, Anda mungkin perlu membuat jarak dengannya.

Organisasi yang terancam dengan kehadiran narsisisme memiliki berbagai pilihan yang dapat digunakan untuk menangani pemimpin narsisistik. Pertama, sebuah organisasi dapat mendorong penggunaan sahabat yang dipercaya untuk bekerja bersama dengan pemimpin narsistik. Banyak narsisis sering mengembangkan hubungan dekat dengan satu orang, seorang sahabat yang dipercaya, yang bertindak sebagai penjaga bagi perilaku mereka. Mitra tepercaya dapat menginformasikan kepada narsisis ketika dia telah melampaui batas dan menempatkan reputasi organisasi dalam bahaya.

Lebih lanjut, pendamping tepercaya dapat membantu pemimpin dalam menangani isu-isu sensitif yang mungkin telah 
berkembang sebagai akibat dari krisis. Sahabat yang tepercaya harus membuat para narsisis percaya bahwa ide yang disampaikannya bertepatan dengan pandangannya (para narsisis) dan kepentingan umum. Pilihan lain yang tersedia untuk organisasi adalah mempertimbangkan untuk mengurangi tingkat kekuasaan narsisis.

Sejumlah perangkat struktural dapat diimplementasikan untuk tugas ini. Sebagai contoh, sebuah organisasi mungkin mempertimbangkan untuk mendistribusikan kembali kekuasaan dalam organisasi, sehingga lebih dari satu orang terlibat dalam membuat keputusan strategis, yang dapat mempengaruhi seluruh organisasi. Komite lintas-fungsi, gugus tugas, dan komite eksekutif dapat menyediakan forum yang bermanfaat di mana banyak manajer dapat mengekspresikan sudut pandang mereka, memberikan kesempatan bagi para pemimpin narsis untuk belajar dari dan mengizinkan pengaruh mereka dikurangi oleh orang.

Pemimpin narsistik tidak memiliki kontrol penuh atas situasi yang berpotensi mengancam organisasi. Pemimpin lain dalam organisasi, yang memiliki kepenting-an dalam kelangsungan hidup organisasi, dapat memberi tahu narsisis tentang cara terbaik untuk menangani situasi tertentu. Organisasi mungkin juga mempertimbang-kan untuk menerapkan survei umpan balik 360 derajat kepada karyawan di dalam perusahaan. Narsisis tidak suka membiarkan perilaku bermasalah mereka terlibat ketika berkomunikasi dengan karyawan di dalam organisasi, terutama jika terjadi krisis. Survei dapat diberikan kepada karyawan setelah setiap latihan dan krisis.

Semua anggota diharapkan untuk memberikan informasi anonim dan rahasia tentang kinerja atasan mereka. Informasi yang dikumpulkan dari survei dapat dibagikan kepada pemimpin krisis, dan membantu manajemen tingkat atas dalam memeriksa kembali pilihan mereka sebagai pemimpin manajemen krisis. Akhirnya, organisasi yang tertarik untuk mempertahankan narsisis, tetapi juga peduli dengan perilaku mereka, mungkin mempertimbangkan untuk menerapkan beberapa bentuk layanan konseling in-house. Konseling atau layanan profesional akan mengirimkan sinyal kuat bahwa pejabat senior peduli dengan kesejahteraan karyawan mereka, organisasi, serta si narsisis itu. Lebih jauh lagi, konseling atau layanan profesional akan memungkinkan narsisis memiliki kesempatan untuk mengakui dan mungkin mereformasi perilakunya, sebelum dihapus secara permanen dari organisasi. (Granville King III, $2007: 10$ )

\section{KESIMPULAN}

Hampir setiap orang memiliki sifat narsistik - mungkin saja menjadi arogan, egois, sombong, atau tidak berelasi, namun tidak menjadi seorang narsisis. Orang-orang dengan gangguan kepribadian narsis adalah orang-orang yang harus dikasihani, dan orang-orang yang membutuhkan untuk dipahami. Sayangnya mereka juga orang-orang yang perlu dikendalikan, dipantau, dan sering dihapus dari posisi yang kuat dan berpengaruh sehingga mereka tidak menghancurkan diri mereka sendiri dan orang lain.

Jika karakteristik destruktif tidak teridentifikasi dan para narsisis dibolehkan untuk melayani dalam lingkup yang luas, masalah serius akan terwujud. Para pendeta gangguan kepribadian narsis bisa sangat kasar dan merusak gereja, dan mendatangkan malapetaka dalam kehidupan pribadi orang-orang terdekat mereka - terutama staf dan kepemimpinan. Narsisis datang dalam berbagai tingkat keparahan dan fungsionalitas, dan berdasarkan tulisan ini Anda harus dapat menentukan kuantitas dan kualitas disfungsi arus situasi Anda, dan segera mengambil tindakan yang penting untuk 
kesejahteraan jemaat, karyawan, kelangsungan hidup organisasi dan juga kebutuhan si narsis itu.

Jika seseorang berada dalam posisi kekuasaan atas orang lain dan ia gagal untuk menempatkan kontrol pada dirinya sendiri, ia secara diam-diam dan tanpa sadar mulai mengendalikan orang lain. Kekuasaan yang mengangkat seorang pemimpin melampaui kontradiksi ... akan membawa pemimpin dan pengikut menyusuri jalan yang ditandai dengan hubungan yang rusak, eksploitasi, dan kontrol. Akan tetapi, kekuasaan yang bersedia untuk mengoreksi diri sendiri dan dibungkus dalam kasih sayang adalah jalan menuju kelembutan, peduli, dan kedewasaan (Weismann, Jurnal Jaffray, 2017: 129). Yesus berkata, "Akulah gembala yang baik, gembala yang baik memberikan nyawanya bagi domba-dombanya" (Yohanes 10:11). Yesus adalah model dalam pelayanan dan kepemimpinan.

\section{DAFTAR PUSTAKA}

Ball, R. Glenn dan Puls, Darel, 2015, Frequecy of Narsisistic Personality Disorder in pastors: A Preliminary Study, American Association of Christian

Counselors, Nashville.

Downing, Karla, Boundaries with a Narcissist, Change My Relationship.com. diakses Oktober 2018 pada http://www.changemyrelation ship.com/c hristian-relationshiphelp-boundaries- with-a$\underline{\text { narcissist/ }}$

King, Granville, 2007, Narcissism and Effective Crisis Management: A Review of Potential Problems and Pitfalls. Journal of Contingencies and Crisis Management, Vol. 15, No. 4, pp. 183-193, December 2007. Dapat diakses pada SSRN: https://ssrn.com/abstract $=1033582$ atau http://dx.doi.org/10.1111/j.14685973.2007.00523.x

Rosenthal, Seth A.,2017, Narcissism and Leadership: A Review and Research Agenda, Harvard University. Dapat diakses pada: https://www.researchgate.net/public ation/279839204_Narcissism_And Leadership_A_Review_And_Resea rch_Agenda

Weismann, Ivan Th. J., 2017, Pelecehan

Rohani dalam Gereja, Kalam Hidup, Bandung

Weismann, Ivan Th. J., 2017 Analisis Faktor Menkanisme Kontrol terhadap Pelecehan Rohani dalam Gereja, Jurnal Jaffray, Vol 15, No.1, hal. 115-130, STT Jaffray, Makassar 


\section{BIODATA PENULIS}

Ivan Thorstein Johannis Weismann lahir di Makassar 28 Februari 1969. Beliau menyelesaikan studi (S1) di STFT Jaffray Makassar, program studi Filsafat Agama Kristen tahun 1987-1992. Melanjutkan studi pascasarjana (S2) di Universitas Gadjah Mada Yogyakarta, program studi Filsafat tahun 1997-2000. Selanjutnya beliau me-nyelesaikan studi doctoral di Universitas Hassanuddin Makassar, program studi Ilmu Sosial tahun 2005-2011. Kemudian beliau mengambil lagi studi doctoral di Universitas Negeri Makassar program studi ilmu pendidikan tahun 2012-2016. Saat ini beliau menjabat sebagai Wakil Ketua I di Bidang Akademik di STFT Jaffray Makassar. 